utmost importance that ethnologists engaged in fieldwork should equip themselves with the necessary knowledge of monetary theory while there is still a possibility of investigating the functioning of the primitive monetary systems which have survived to our day.

'Layard, G., "Stone Men of Malekula" (London, 1937), pp. 252-3 ; Harrison, T., "Savage Civilization" (London, 1937), pp. 26-28. "Codrington, R. H., "The Melanesians" (Oxford, 1881), p. 236.

"Mead, Margaret, "Growing Up in New Guinea" (London, 1931), p. 218; Fortune, R. F., "Manus' Religion and Ethnological delphia, 1936), pp, 49-50.

"Du Bois, Cora, "The People of Alor" (Minneapolis, 1944), pp. 143-5. 'Mill, John Stuart, "Principles of Political Economy" (London, 1878), p. 4.

\section{VITAMINS AND ANTI-VITAMINS}

A $\mathrm{N}$ interesting discussion on "Anti-vitamins in A Food", arranged by the Nutrition Society, took place on October 23 at the Royal Society of Arts. Sir Edward Mellanby, who might justly claim to be the originator of the modern concept of anti-vitamins, was chairman. In his introductory remarks he pointed out that the 'anti-vitamin' or 'toxamin' theory is now some twenty years old, although his early claims that cereals must contain substances which antagonize vitamin $\mathrm{D}$ had not been immediately accepted. Later work, however, in identifying phytic acid as an anti-calcifying factor, had placed the existence of anti-vitamins beyond dispute. Considerable progress is now being made towards an understanding of the general principles underlying the mode of action of the anti-vitamins, and both their significance as dietary factors and their potentialities as therapeutic agents are clearly recognized.

\section{Natural and Artificial Anti-vitamins}

Dr. L. J. Harris recalled that Eijkmann, who shared a Nobel Prize with the late Sir Frederick Gowland Hopkins for the discovery of vitamins, resorted to what amounted to an 'anti-vitamin' theory to explain the results of his experiments on avian polyneuritis. Since a diet of polished rice caused polyneuritis, while rice polishings cured this condition, he assumed that the rice contained a toxin and the polishings an antidote. Hopkins, on the other hand, proved the reality of 'deficiency diseases', in which injury is caused simply by the absence of a vitamin from the diet, and not by failure of the vitamin to neutralize a dietary toxin. While Hopkins' conclusions have proved substantially correct, it is now realized that the adequacy or inadequacy of a diet in regard to a particular vitamin may often be influenced by the other constituents of the diet. Since the requirement of the organism for vitamin $B_{1}$ has been found to be proportional to the carbohydrate intake, we may regard the starch present in Eijkmann's polished rice as being antagonistic to the vitamin $B_{1}$ present in the polishings. In this limited sense, therefore, it may be considered a toxic substance.

The important work of Mallanby on the rachitogenic properties of cereal products, however, indicated that some foods contain substances, other than their major components, which antagonize the action of vitamins. Another important advance resulted from the demonstration by Fildes and Woods that the sulphonamide drugs owe their bacteriostatic action to their biological competition with $p$-amino-benzoic acid, a compound with a similar chemical structure which has since been recognized as a vitamin. The sulphonamides may therefore be regarded as artificial anti-vitamins, and, on the same principle, analogues inhibiting the action of most of the other vitamins have now been synthesized. Although it was not intentionally chosen as an anti-vitamin, the familiar insecticide 'Gammexane', or hexa-chloro-benzene, presumably owes its activity to its competition with the vitamin inositol, the corresponding hexa-hydroxy compound.

In estimations of vitamins in foodstuffs by biological tests, the results obtained will depend not only on the amounts of vitamin present but also on the amounts of anti-vitamin, as well as on the presence of substances which assist the vitamin in its absorption and utilization, and many other factors. Chemical tests, on the other hand, tell us how much vitamin is present, without enlightening us as to its degree of availability to the animal. Since both chemical and biological methods give results which are perfectly correct, within the limitations recognized in each case, it is obviously essential that in quoting vitamin values for foodstuffs the method used should be clearly stated.

\section{Anti-B-vitamins}

The numerous B-vitamins in themselves present a very complicated picture, which is made even more complex when we extend our studies to the corresponding anti-vitamins. Many B-vitamins, moreover, are synthesized by the intestinal bacteria, in amounts which differ widely in different animals, with the result that anti-vitamins may either affect the organism directly or through the agency of the intestinal flora. Altogether, Dr. E. Kodicek has enumerated five ways in which the action of B-vitamins may be inhibited, including (1) failure of intestinal absorption, (2) the destruction or inactiv. ation of the vitamin by toxic substances or bacteria, (3) the inhibition of bacteria producing the vitamin by antagonists or the absence of an essential meta. bolite, (4) the displacement of the vitamin from the tissues by analogues, and (5) exposure of the organism to special stiesses, such as infections, pregnancy, and a bad balance of the major components of the diet.

Various types of 'toxamins' may oppose the action of B-vitamins, but the term 'anti-vitamin' is perhaps best reserved for the structural analogues, which have already been synthesized in relation to aneurin, nicotinic amide, riboflavin, vitamin $B_{6}$, pteroyl glutamic acid, pantothenic acid, biotin, choline and inositol. Several natural toxamins have also been reported, including the thiaminase in live yeast which destroys vitamin $B_{1}$, a factor in maize which antagonizes nicotinic amide, the avidin of raw egg white which inactivates biotin, and the lycomarasmin of wilted tomato plants which antagonizes the bacterial growth-factor, streptogenin.

\section{Rachitogenic and Hæmorrhagenic Toxamins}

Phytic acid, a phosphorylated derivative of inositol, is the best known anti-calcifying agent in foodstuffs. Prof. R. A. McCance pointed out that evidence of the rachitogenic properties of cereal products was advanced by Mellanby in 1920; but it was not until about ten years later that Bruce and Callow found that phytic acid interferes with the absorption of calcium. Harrison and Mellanby then demonstrated that this substance had the same effect as cereals in causing rickets in dogs, while 
McCance and his colleagues found in human feeding trials that the absorption of calcium was less efficient with wholemeal bread than with white bread as the main constituent of the diet. The addition of calcium to National flour was therefore undertaken in order to compensate for the increased amounts of phytic acid which resulted from the higher extraction-rate.

Unidentified rachitogenic agents have also been encountered in animal feeding-stuffs. Yeast is a valuable source of proteins and B-vitamins for pigs; but Dr. S. K. Kon and his colleagues have found that it causes rickets unless cod-liver oil, or some other source of vitamin D, is also given. Dr. T. K. Ewer has observed rickets in sheep reared in the southern island of New Zealand, where young green cereals are used as fodder. The condition responds to treat. ment with vitamin D; exposure to sunlight, however, is not effective, the tendency to rickets being greatest when good weather causes a rapid growth of the fodder.

Fatal hæmorrhages, associated with a prolonged blood-clotting time, have long been known to occur in cattle fed upon defectively cured sweet-clover, and Link and his colleagues identified the toxic agent as dicoumarin. Since full protection against the action of this substance may be secured by the administration of vitamin $K$, it may be regarded as a typical toxamin in the sense implied by Mellanby. Dr. P. Meunier, of Lyons, has studied the quantitative balance between hæmorrhagenic agents and vitamin $K$ in the rabbit. Several synthetic analogues, including phenyl indanedione, have been found to cause increased clotting times, although they are generally less active than dicoumarin.

\section{Imbalance of Fat-soluble Vitamins}

Under this heading, Dr. T. Moore discussed the effects of toxic overdosing with one vitamin, and also the effects of deficiency or excess of various nutrients on the activity of the fat-soluble vitamins. Thus, massive overdosage with vitamin A leads in rats to skeletal fractures and hæmorrhages which are reminiscent of scurvy, while this disease has also been diagnosed in an American child given absurdly large doses of vitamin A. It has been reported that vitamin A deficiency causes a secondary deficiency of vitamin $\mathrm{C}$ in rats and silver foxes; but the significance of this vitamin in both deficiency and excess of vitamin A remains undecided. Hypervitaminosis $A$ in rats, however, undoubtedly leads to a prolonged blood-clotting time which can be corrected by giving vitamin $\mathbf{K}$.

The demands of the organism for carotene or vitamin A may be influenced by many factors. Extensive animal experiments have indicated that vitamin E, a powerful antioxidant, protects vitamin A from destruction in foodstuffs during storage, in the products of their partial digestion passing through the intestinal tract, and in the tissues of the consumer. In the human subject the habitual use of medicinal paraffin may seriously interfere with the absorption of carotene. Early work by Mellanby indicated that certain cereal products, and also ergot of rye, may emphasize the effect of vitamin $A$ deficiency in causing nervous lesions, which his later work has associated with disordered growth of bone.

Massive overdosage with vitamin $\mathbf{D}$ causes excessive calcification, and doses approaching the toxic level have been found by Charpy and by Dowling to be valuable in the treatment of cutaneous tuberculosis.
Deficiency of vitamin $\mathrm{E}$ in experimental animals causes not only reproductive failure but also many other lesions including muscular dystrophy, brown pigmentation of the uterus and adipose tissues, exudative diathesis, encephalomalacia, renal abnorm. alities and dental depigmentation. Most of these lesions are increased in severity by an inadequate protein allowance, and by the inclusion in the diet of cod-liver oil or other highly unsaturated fats. Conversely, the lesions may be avoided or reduced in severity by removing fats from the diet, and by including adequate amounts of protein, choline, methionine and inositol. In general, therefore, liability to the effects of vitamin $\mathrm{E}$ deficiency is increased by the consumption of readily oxidizable fats, and decreased by adequate dietary supplies of the lipotropic factors which facilitate the mobilization and transference of fats.

Mr. A. L. Bacharach summarized the day's proceedings, and expresssed his satisfaction in the success of the meeting in bringing together a mass of information on an interesting and important subject.

\section{OBITUARY}

Sir John Fryer, K.B.E., F.R.S.

Agricultural science has suffered a severe loss by the death on November 22 of Sir John Fryer, secretary of the Agricultural Research Council, at the age of sixty-two. The news came as a great shock to his many friends both in scientific and administrative circles.

John Claud Fortescue Fryer was born on August 13,1886 . His family had been farmers in Cambridgeshire and Huntingdonshire for generations, and his early years were spent at Chatteris in the fenlands; he was always happy to return to the East Anglian countryside. He was at school at Rugby and went on to Gonville and Caius College, Cambridge, where he took a first class in the Natural Sciences Tripos and a little later was elected a fellow of the College. $\mathrm{He}$ already had a good knowledge of British insects and, like his father and grandfather before him, was a keen collector and field naturalist. Some years abroad followed. He joined the Percy Sladen Ex. pedition to Aldabra Island, in the Indian Ocean, and wrote a valuable account of the natural history of the island; he also spent some time in Ceylon where he worked on the genetics of the butterfly Papilio polytes. On returning to England, Fryer was appointed entomologist to the Ministry (then Board) of Agriculture, and devoted himself to the study of insects of economic importance in agriculture and horti. culture. It was a new post and he started work in an office in Northumberland Avenue without laboratory accommodation or equipment. After a pioneering period, a small staff of entomologists and plant pathologists was recruited and the Ministry's Plant Pathology Laboratory established. Accommodation was found for a time at $\mathrm{Kew}$, and in 1920 a move was made to permanent quarters at Harpenden, where Fryer made his home. As director of the Laboratory, he took a leading part in dealing with a great variety of problems and inquiries concerming insect and other pests of crops, in fostering and initiating research on control measures, and in establishing an efficient advisory service in these subjects throughout Great Britain. One of his major problems was the continually increasing threat of the 